\title{
Distribution and habitats of Bulinus depressus and possible role as intermediate host of economically important helminth parasites in South Africa
}

\author{
KN de Kock* and CT Wolmarans \\ School of Environmental Sciences and Development, Zoology, Potchefstroom Campus of the North-West University, \\ Private Bag X6001, Potchefstroom 2520, South Africa
}

\begin{abstract}
This article documents the large-scale spatial distribution and ecological descriptors of associated habitats of Bulinus depressus by analysis of samples taken from 552 collection sites on record in the database of the National Freshwater Snail Collection (NFSC) at the Potchefstroom Campus of the North-West University. This snail species is experimentally susceptible to Schistosoma margrebowiei, a helminth parasite of game animals and cattle and can possibly also exploit humans as definitive hosts. The 125 different loci $(1 / 16$ degree squares) on record reflect a geographical distribution that is largely limited to the central and western part of the Limpopo Province and westwards down the basins of the Vaal and Orange Rivers. Details of each habitat as described by collectors during surveys, as well as altitude and mean annual air temperature and rainfall for each locality, were processed and chi-square and effect size values calculated. A decision tree constructed from all the available data indicated that temperature and altitude, followed by the type of water-body, seemed to be the more important factors that significantly influenced the distribution of this species in South Africa. The possible role of this species as intermediate host of economically important helminth species is briefly looked at and the urgent need to update the geographical distribution of host snails is emphasised. It is recommended that efforts be made to determine the exact role of $B$. depressus in the epidemiology of economically important helminth parasites.
\end{abstract}

Keywords: Bulinus depressus, geographical distribution, habitat preferences, Schistosoma margrebowiei

\section{Introduction}

Bulinus depressus belongs to the family Planorbidae that has a wide geological distribution and is the most heterogeneous group of snails in the Basommatophora (Demian, 1960). Originally described by Haas (1936) from Lake Bangweulu, Zambia, this author drew attention only to those conchological characteristics that to him seemed distinctive of the new species. These features unfortunately subsequently proved to be insufficient to characterise it and resulted in a disagreement between malacologists as to what $B$. depressus actually was (HamiltonAttwell and Van Eeden, 1969). Mandahl-Barth (1968) regarded B. depressus as a subspecies of Bulinus tropicus after examining similar snails from Zambia with non-angular mesocones on the radula. However, in the course of large-scale freshwater snail surveys conducted in South Africa since 1956 many samples identified as $B$. depressus (Van Eeden et al., 1965), were found to have strongly angular mesocones and to be often aphallic (Schutte, 1966; Hamilton-Attwell and Van Eeden, 1969). At that stage $B$. depressus was considered to be part of the $B$. truncatus group. Electrophoresis of proteins from the eggs of $B$. depressus (Hamilton-Attwell, 1976), however, yielded a single-banded main fraction consistent with the diploid chromosome number (Brown, 1994) in contrast to the tetraploid chromosome number characteristic of B. truncatus. According to Brown (1994) the Bulinus species may be divided into groups that have their origins in the four species groups of Mandahl-Barth (1957), namely B. africanus, B. truncatus, B. tropicus and B. forskalii.

\footnotetext{
* To whom all correspondence should be addressed.

용 +2718 299 2380; fax: +2718 2992370 ;

e-mail: drkkndk@puknet.puk.ac.za

Received 13 June 2004; accepted in revised form 18 August 2005.
}

However, the groups discussed by Brown (1994) differ in the separation of a $B$. reticulatus group (Wright, 1971) and the fusion of Mandahl-Barth's groups for B. truncatus and B. tropicus into a single B. truncatus/tropicus complex (Brown, 1980; 1981). Bulinus depressus is regarded by Brown (1994) as part of this complex.

This report focuses on the geographical distribution and habitats of $B$. depressus as reflected by the 552 samples in the database of the National Freshwater Snail Collection of South Africa (NFSC). Details of each habitat, as well as mean altitude and mean annual air temperature and rainfall for each locality, were processed to determine chi-square and effect size values. An integrated decision tree that is a statistical model enabling the selection and ranking of those variables that can maximally discriminate between the frequency of occurrence of a given species under specific conditions as compared to all other species in the database was also constructed. The results indicated that altitude, temperature and type of water-body seemed to be some of the major factors determining the distribution of this species in South Africa. On account of the great variation among species of the genus Bulinus in respect of compatibility with schistosomes (Brown, 1994), the role of B. depressus as intermediate host of economically important helminth parasites in South Africa is briefly discussed.

\section{Methods}

Data pertaining to the habitats and geographical distribution of $B$. depressus were extracted from the database of the NFSC, which dates from 1956 up to the present. Only samples for which the collection sites could be pinpointed on the 1:250 000 topocadastral map series of South Africa, were included in the analy- 


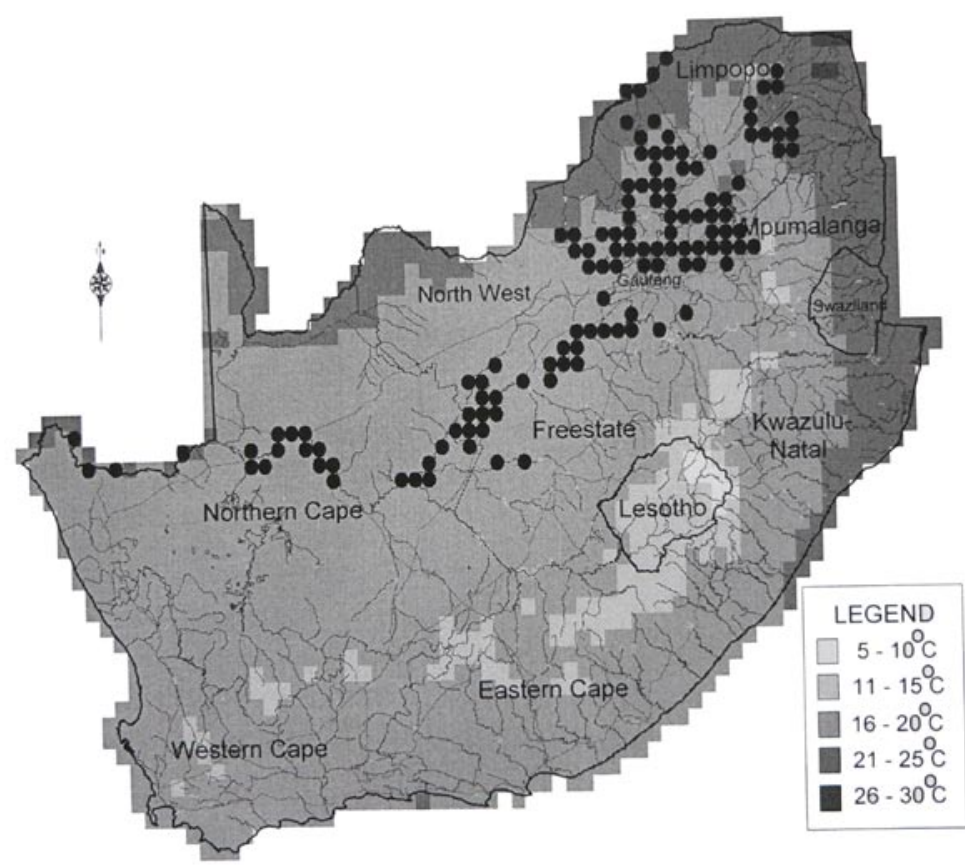

Figure 1

The geographical distribution of Bulinus depressus in $1 / 16$ square degree loci and mean annual air temperature in South Africa

\begin{tabular}{|c|c|c|c|c|}
\hline \multicolumn{5}{|c|}{$\begin{array}{c}\text { TABLE 1 } \\
\text { Types of water-body from which Bulinus } \\
\text { depressus was recorded by collectors } \\
\text { during surveys }\end{array}$} \\
\hline Water-bodies & A & B & C & D \\
\hline Concrete dam & 5 & $0.9 \%$ & 221 & $2.3 \%$ \\
\hline Dam & 168 & $30.4 \%$ & 8400 & $2.0 \%$ \\
\hline Ditch & 10 & $1.8 \%$ & 636 & $1.6 \%$ \\
\hline Pan & 2 & $0.4 \%$ & 306 & $0.7 \%$ \\
\hline Pool & 2 & $0.4 \%$ & 225 & $0.9 \%$ \\
\hline Quarry & 1 & $0.2 \%$ & 122 & $0.8 \%$ \\
\hline River & 163 & $29.5 \%$ & 7507 & $2.2 \%$ \\
\hline Spring & 1 & $0.2 \%$ & 301 & $0.3 \%$ \\
\hline Stream & 55 & $10.0 \%$ & 7211 & $0.8 \%$ \\
\hline Swamp/Marsh & 7 & $1.3 \%$ & 2076 & $0.3 \%$ \\
\hline \multicolumn{5}{|c|}{ Effect size $w=0.44$ (moderate to large effect) } \\
\hline \multicolumn{5}{|c|}{ 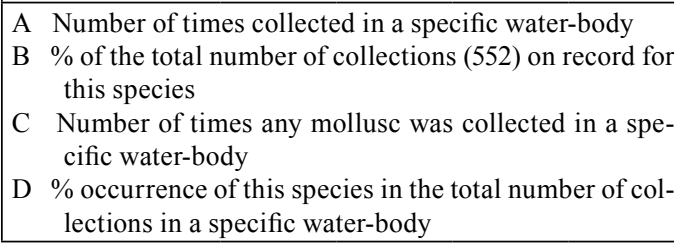 } \\
\hline
\end{tabular}

sis. The majority of these samples were collected during surveys conducted by staff of government and local health authorities and then dispatched to the former Snail Research Unit at the Potchefstroom University (now University of the North-West) for identification and to be added to the NFSC.

Details of the habitats were recorded by collectors during surveys by selecting the relevant options on forms compiled by the staff of the Snail Research Unit. The number of loci in which the collection sites were located was distributed in intervals of mean annual rainfall and air temperature, as well as intervals of mean altitude to illustrate the frequency of occurrence within specific intervals. Rainfall, temperature and altitude data were obtained in 2001 from the Computing Centre for Water Research (disbanded since), University of KwaZulu-Natal. A temperature index was calculated for all mollusc species in the database from their frequencies of occurrence within the selected temperature intervals and the results used to rank them in order of association with low to high climatic temperatures. This was done by allocating numeric values, ranging from one for the coolest to five for the warmest, to the five selected temperature intervals. The proportion of the total number of loci of each species falling within a particular temperature interval was then multiplied by the value allocated to that specific temperature interval. This was done for each temperature interval in which the species was recorded and the sum of these scores was then taken as the temperature index for that particular species and the results presented in Table 5 (Brown, 2002; De Kock and Wolmarans, 2005). Chi-square values were calculated to determine the significance in difference between the frequency of occurrence in, on, or at the different options for each variable, such as type of water-body, type of substratum and temperature interval. Furthermore, an effect size (Cohen, 1977) was calculated for all the different variables discussed in this paper. The effect size is an index which measures the degree of discrepancy between the frequency distribution of a given species in the set of alternatives of a given variable such as water-bodies, as compared to the frequency distribution of all other mollusc species in the database in the set of alternatives of the same variable (Cohen, 1977). According to this author values for this index in the order of 0.1 and 0.3 indicate small and moderate effects respectively, while values of 0.5 and higher indicate practical significantly large effects. A value for this index in the order of 0.5 , calculated for the frequency distribution of a given mollusc species in the different types of water-body, for instance, would indicate that this factor played an important role in determining the geographical distribution of this particular species as reflected by the data in the database.

The data were also processed to construct an integrated decision tree (Breiman et al., 1984). This is a statistical model that enables the selection and ranking of those variables that can maximally discriminate between frequencies of occurrence of a given species under specific conditions as compared to all other species in the database. This was accomplished by making use of the SAS Enterprise Miner for Windows NT Release 4.0, April 19, 2000 programme and Decision Tree Modelling Course Notes (Potts, 1999).

\section{Results}

The 552 samples of $B$. depressus that could be pinpointed on our maps were collected from 125 different loci (Fig. 1). Although this species was recorded from 10 of the 14 water-body types represented in the database, dams (30.4\%) and rivers (29.5\%) accounted for nearly $60 \%$ of the total number of samples (552) for this species in the database (Table 1). However, the five times it was recovered from concrete dams represented $2.3 \%$ of the total number of collections of all species from concrete dams, which compares favourably with the percentages recorded for dams and rivers in this respect (Table 1). Consequently its frequency of occurrence in dams and rivers did not differ significantly from the figure for concrete dams (chi-square values: dams and concrete dams: $\chi^{2}=0.08, d f=1 ; \mathrm{p}>0.05$; rivers and 
TABLE 5

Frequency distribution in temperature intervals and temperature index of Bulinus depressus as compared to all mollusc species in the database of the National Freshwater Snail Collection

\begin{tabular}{|c|c|c|c|c|c|c|c|c|c|c|}
\hline Mollusc species & \begin{tabular}{|c|} 
No. of \\
samples
\end{tabular} & $5-10^{\circ} \mathrm{C}$ & $11-15^{\circ} \mathrm{C}$ & $16-20^{\circ} \mathrm{C}$ & $21-25^{\circ} \mathrm{C}$ & $26-30^{\circ} \mathrm{C}$ & ${ }^{1}$ Index & ${ }^{2} \mathrm{SD}$ & ${ }^{3} \mathrm{CV}$ & $\begin{array}{c}\text { Effect } \\
\text { size }\end{array}$ \\
\hline Pisidium viridarium & 636 & 201 & 270 & 163 & 2 & & 1.947 & 0.764 & 39.22 & -4.698 \\
\hline Lymnaea truncatula & 723 & 95 & 281 & 343 & 4 & & 2.354 & 0.709 & 30.14 & -2.979 \\
\hline Pisidium casertanum & 5 & & 2 & 3 & & & 2.600 & 0.548 & 21.07 & -1.941 \\
\hline Pisidium langleyanum & 627 & 18 & 173 & 430 & 6 & & 2.676 & 0.544 & 20.33 & -1.619 \\
\hline Pisidium costulosum & 425 & 1 & 138 & 282 & 4 & & 2.680 & 0.492 & 18.34 & -1.603 \\
\hline Bulinus tropicus & 8448 & 32 & 2326 & 5860 & 230 & & 2.744 & 0.502 & 18.31 & -1.332 \\
\hline Gyraulus connollyi & 969 & & 185 & 777 & 7 & & 2.816 & 0.406 & 14.40 & -1.028 \\
\hline Ceratophallus natalensis & 1797 & & 299 & 1430 & 68 & & 2.871 & 0.433 & 15.09 & -0.796 \\
\hline Burnupia (all species) & 2778 & 7 & 287 & 2384 & 100 & & 2.928 & 0.380 & 12.97 & -0.558 \\
\hline Ferrissia (all species) & 540 & & 72 & 420 & 47 & 1 & 2.957 & 0.476 & 16.09 & -0.433 \\
\hline Bulinus reticulatus & 296 & & 6 & 287 & 3 & & 2.990 & 0.174 & 5.83 & -0.296 \\
\hline Assiminea umlaasiana & 2 & & & 2 & & & 3.000 & 0.000 & 0.00 & -0.253 \\
\hline Tomichia cawstoni & 4 & & & 4 & & & 3.000 & 0.000 & 0.00 & -0.253 \\
\hline Tomichia diferens & 10 & & & 10 & & & 3.000 & 0.000 & 0.00 & -0.253 \\
\hline Tomichia lirata & 2 & & & 2 & & & 3.000 & 0.000 & 0.00 & -0.253 \\
\hline Tomichia ventricosa & 89 & & & 89 & & & 3.000 & 0.000 & 0.00 & -0.253 \\
\hline Tomichia tristis & 81 & & & 79 & 2 & & 3.025 & 0.156 & 5.16 & -0.149 \\
\hline Unio caffer & 76 & & 6 & 63 & 6 & 1 & 3.026 & 0.461 & 15.24 & -0.142 \\
\hline Physa acuta & 755 & & & 719 & 36 & & 3.048 & 0.213 & 7.00 & -0.052 \\
\hline Bulinus depressus & 552 & & & 519 & 33 & & 3.060 & 0.237 & 7.76 & 0.000 \\
\hline Arcuatula capensis & 15 & & & 14 & 1 & & 3.067 & 0.258 & 8.42 & 0.028 \\
\hline Lymnaea columella & 2302 & & 81 & 1977 & 243 & 1 & 3.071 & 0.371 & 12.07 & 0.047 \\
\hline Lymnaea natalensis & 4721 & & 205 & 3802 & 713 & 1 & 3.108 & 0.429 & 13.79 & 0.023 \\
\hline Assiminea bifasciata & 17 & & & 15 & 2 & & 3.118 & 0.332 & 10.65 & 0.243 \\
\hline Gyraulus costulatus & 736 & & 20 & 580 & 135 & 1 & 3.159 & 0.437 & 13.84 & 0.418 \\
\hline Bulinus forskalii & 1209 & & 17 & 985 & 204 & 3 & 3.160 & 0.409 & 12.95 & 0.420 \\
\hline Pisidium ovampicum & 6 & & & 5 & 1 & & 3.167 & 0.408 & 12.89 & 0.450 \\
\hline Sphaerium capense & 25 & & 1 & 17 & 7 & & 3.240 & 0.523 & 16.14 & 0.759 \\
\hline Bulinus africanus group & 2930 & & 9 & 2155 & 760 & 6 & 3.260 & 0.450 & 13.82 & 0.846 \\
\hline Corbicula fluminalis & 389 & & 1 & 291 & 94 & 4 & 3.267 & 0.437 & 13.38 & 0.875 \\
\hline Tomichia natalensis & 23 & & & 16 & 7 & & 3.304 & 0.470 & 14.24 & 1.031 \\
\hline Thiara amarula & 10 & & & 6 & 4 & & 3.400 & 0.516 & 15.19 & 1.435 \\
\hline Assiminea ovata & 5 & & & 3 & 2 & & 3.400 & 0.548 & 16.11 & 1.435 \\
\hline Melanoides victoriae & 49 & & & 29 & 19 & 1 & 3.429 & 0.540 & 15.75 & 1.555 \\
\hline Biomphalaria pfeifferi & 1639 & & 5 & 880 & 751 & 3 & 3.459 & 0.508 & 14.69 & 1.683 \\
\hline Septaria tesselaria & 2 & & & 1 & 1 & & 3.500 & 0.707 & 20.20 & 1.857 \\
\hline Coelatura framesi & 6 & & & 3 & 3 & & 3.500 & 0.548 & 15.65 & 1.857 \\
\hline Neritina natalensis & 16 & & & 8 & 8 & & 3.500 & 0.516 & 14.75 & 1.857 \\
\hline Bulinus natalensis & 244 & & 2 & 97 & 145 & & 3.588 & 0.510 & 14.20 & 2.227 \\
\hline Segmentorbis planodiscus & 27 & & & 9 & 18 & & 3.667 & 0.480 & 13.10 & 2.560 \\
\hline Segmentorbis angustus & 32 & & & 7 & 25 & & 3.781 & 0.420 & 11.11 & 3.043 \\
\hline Melanoides tuberculata & 305 & & & 64 & 237 & 4 & 3.803 & 0.430 & 11.30 & 3.136 \\
\hline Pisidium pirothi & 23 & & & 4 & 19 & & 3.826 & 0.388 & 10.13 & 3.232 \\
\hline Spathopsis wahlbergi & 36 & & & 7 & 28 & 1 & 3.932 & 0.398 & 10.11 & 3.679 \\
\hline Aplexa marmorata & 9 & & & & 9 & & 4.000 & 0.000 & 0.00 & 3.966 \\
\hline Bellamya capillata & 31 & & & & 31 & & 4.000 & 0.000 & 0.00 & 3.966 \\
\hline Eupera ferruginea & 169 & & & 6 & 157 & 6 & 4.000 & 0.267 & 6.68 & 3.966 \\
\hline Lentorbis carringtoni & 8 & & & & 8 & & 4.000 & 0.000 & 0.00 & 3.966 \\
\hline Lentorbis junodi & 12 & & & & 12 & & 4.000 & 0.000 & 0.00 & 3.966 \\
\hline Segmentorbis kanisaensis & 9 & & & & 9 & & 4.000 & 0.000 & 0.00 & 3.966 \\
\hline Spathopsis petersii & 39 & & & 1 & 36 & 2 & 4.000 & 0.272 & 6.80 & 3.966 \\
\hline Cleopatra ferruginea & 73 & & & & 71 & 2 & 4.027 & 0.164 & 4.08 & 4.082 \\
\hline Lanistes ovum & 41 & & & & 38 & 3 & 4.073 & 0.264 & 6.47 & 4.275 \\
\hline
\end{tabular}




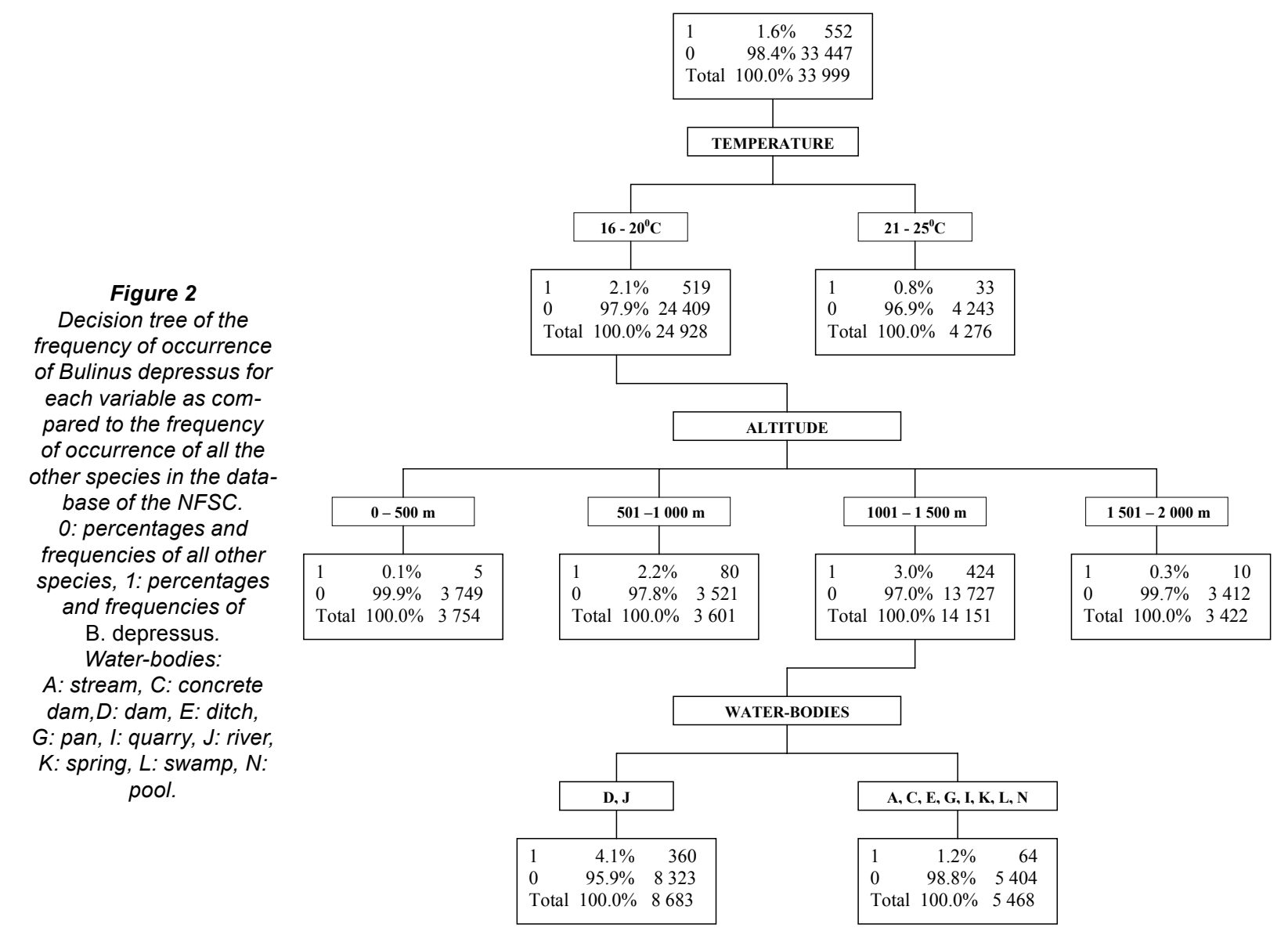

to $1500 \mathrm{~m}$ (Table 4). The frequency of occurrence within this interval differed significantly from the other intervals (chisquare values ranging from $\chi^{2}=158.0, d f=1 ; \mathrm{p}<0.05$ to $\chi^{2}=$ 180.6, $d f=1 ; \mathrm{p}<0.05$ ) except from the 501 to $1000 \mathrm{~m}$ interval where the chi-square-value indicated no significant difference at all $\left(\chi^{2}=3.5, d f=1 ; \mathrm{p}>0.05\right)$.

The effect size values calculated for all the factors investigated are given in Tables 1 to 4 and the temperature indexes of all mollusc species in the database, as well as the effect sizes to evaluate their significance in difference as compared to $B$. depressus, are listed in Table 5 and the decision tree analysis depicted in Fig. 2.

\section{Discussion}

Bulinus depressus was reported from all the provinces of South Africa except the Western and Eastern Cape and KwaZuluNatal Provinces and is well represented in the basins of the Vaal and Orange Rivers and further westwards towards the mouth of the Orange River (Fig. 1). This is in general agreement with the geographical distribution reported by Brown (1994) for this species in South Africa. Initially described by Haas (1936) from specimens collected in a canal flowing into Lake Bangweulu, this species was subsequently reported from the same region by Mandahl-Barth (1968). Elsewhere in Africa it was reported from Zaire (Mandahl-Barth et al., 1972) and from the Okavango River and East Caprivi (Brown et al., 1992).

The effect size values calculated for the various factors investigated (Tables 1 to 4 ) indicated that altitude, temperature, rainfall and water-bodies, in that order, had a large to moderate effect $(w>0.05)$ on the geographical distribution of $B$. depressus in South Africa and these observations were corroborated by the results of the decision tree analysis depicted in Fig. 2.

Dams and rivers seemed to be the type of water-body of choice as indicated by its frequency of occurrence in these types of water-body (Table 1). The results of both the decision tree and chi-square analyses indicated a significant difference between these two types of water-body and the rest of the types of waterbody investigated. These observations and the fact that it was also recovered from cement-lined reservoirs and marshes (Table 1), is in accordance with reports in literature by several authors (Schutte, 1966; Mandahl-Barth, 1968; Hamilton-Attwell and Van Eeden, 1969; Mandahl-Barth et al., 1972).

Although $B$. depressus is not included in a list in which the common African freshwater snails were arranged in groups according to their ability to aestivate (Brown, 1994), 46 of the samples in the database of the NFSC were recovered from habitats described as seasonal (Table 2) and this species was also reported from a temporary marsh by Mandahl-Barth et al. (1972). From this it can be deduced that it might have some ability to aestivate, like the majority of the other Bulinus species.

The first records of both $B$. depressus and the closely related B. tropicus in the database of the NFSC date back to the early 1950 s but the 552 samples on record for the former, compare poorly to the 8448 samples on record for the latter (Table 5). Likewise the 125 different loci recorded for $B$. depressus (Fig. 1) compare poorly to the 939 different loci reported for B. tropicus by De Kock et al. (2002), reflecting a much narrower geographical distribution. A decision tree analysis (Fig. 2) selected temperature as one of the more important factors determining the geographical distribution of both these species in South Africa (Fig. 2; De Kock et al., 2002). Scrutiny of Table 5 , however, reveals that the temperature index calculated for B.tropicus (2.744)differssignificantly(effectsize $>0.5$ ) fromthat of 
B. depressus (3.060) and also indicates a closer association with cooler temperatures. This implies that the former species should be better adapted to colonise cooler parts of the country. Furthermore, $B$. depressus was recovered from sites falling into only two of the five selected temperature intervals as compared to the four recorded for B. tropicus (Table 5).

Field-collected and laboratory-reared specimens of B. depressus from the Limpopo Province, South Africa, were not susceptible to infection with either Schistosoma haematobium or S. mattheei (Schutte, 1966). However, laboratory infections with $S$. margrebowiei have been achieved by Pitchford and Du Toit (1976) and according to Pitchford (1976) the definite host range of this schistosome species includes six game genera, cattle and possibly man. Although $B$. depressus is not included in the list of snails found to harbour natural infections of amphistome parasites of grazing animals, specimens of two of the closely related diploid species, B. tropicus and B. natalensis were both reported to harbour natural infections of the conical fluke, Calicophoron microbothrium (Brown, 1994). In the process of the preparation of microscope slides of the radula and penis complex of the 552 samples of $B$. depressus in the NFSC, immature parasite stages were observed in many of these specimens and field specimens kept alive in the laboratory for experimental purposes also shed amphistome cercariae on several occasions (personal observations). Unfortunately the identity of these immature parasite stages was never established.

In an earlier publication (De Kock and Wolmarans, 2005) the authors emphasised the need for coordinated surveys to update the knowledge of the current distribution of the freshwater snails in South Africa. The most recent record of B. depressus in the NFSC dates back to 1989 and in view of the fact that this species is susceptible to schistosome parasites of certain game animals and possibly of man and could perhaps also play a role in the transmission of the conical fluke of cattle, C. microbothrium, it is recommended that efforts be made to update the geographical distribution of $B$. depressus and to clear up its role in the transmission of economically important helminth parasites in South Africa.

\section{Acknowledgements}

We are indebted to Prof HS Steyn, head of the Statistical Consulting Service and Prof DA de Waal of the Centre for Business Mathematics and Informatics of the Potchefstroom Campus of the North-West University for their assistance in processing the data and to the National Research Foundation (NRF) and the Potchefstroom Campus of the North-West University for financial support and permission to publish.

\section{References}

BREIMAN L, FRIEDMAN JH, OLSHEN RA and STONE CJ (1984) Classification and Regression Trees. Chapman and Hall.

BROWN DS (1980) Freshwater Snails of Africa and their Medical Importance. Taylor \& Francis, London.
BROWN DS (1981) Generic nomenclature of freshwater snails commonly classified in the genus Bulinus (Mollusca: Basommatophora). J. Nat. Hist. 15 909-915.

BROWN DS (1994) Freshwater Snails of Africa and Their Medical Importance (Revised $2^{\text {nd }}$ edn.) Taylor \& Francis, London.

BROWN DS (2002) Personal communication. Dept. of Zoology, The Natural History Museum, London (Dr. David Seymour Brown passed away on 25 March 2004).

BROWN DS, CURTIS BA, BETHUNE S and APPLETON CC (1992) Freshwater snails of East Caprivi and the lower Okavango River Basin in Namibia and Botswana. Hydrobiol. 246 9-40.

COHEN J (1977) Power Analysis for the Behaviour Sciences (revised edn.) Academic Press, Orlando.

DE KOCK KN and WOLMARANS CT (2005) Distribution and habitats of the Bulinus africanus species group, snail intermediate hosts of Schistosoma haematobium and S. mattheei in South Africa. Water SA 31 (1) 117-126.

DE KOCK KN, WOLMARANS CT, BORNMAN, M and MAREE DC (2002) Verspreiding en habitats van Bulinus tropicus, tussengasheerslak van die peervormige bot Calicophoron microbothrium, in Suid-Afrika. SA Tydskr. Natuurwet. Teg. 21 (4) 114-120.

DEMIAN ES (1960) Morphological studies on the Planorbidae of Egypt. 1. On the microscopic anatomy of Bulinus (Bulinus) truncatus (Audouin). Ain Shams Sci. Bull. 5 1-84.

HAAS F (1936) Binnen-Mollusken aus Inner-Afrika. Abh. Senckenber. Naturforsch. Gesell. 431 1-156.

HAMILTON-ATTWEL VL (1976) Electrophoresis of the perivitelline fluid of molluscan eggs: 4 . Protein characteristics determining the taxonomic position of Bulinus (Bulinus) depressus Haas and B. (B.) natalensis (Küster). Wetenskaplike Bydraes van die $\mathrm{PU}$ vir $\mathrm{CHO}$, Reeks B: Natuurwetenskappe 76 1-37.

HAMILTON-ATTWEL VL and VAN EEDEN JA (1969) The shell, radula pallial organs and reproductive system of Bulinus (Bulinus) depressus Haas (Mollusca: Basommatophora). Wetenskaplike Bydraes van die PU vir CHO, Reeks B: Natuurwetenskappe 9 1-54.

MANDAHL-BARTH G (1957) Intermediate hosts of Schistosoma. African Biomphalaria and Bulinus. II. Bull. World Health Org. 17 $1-65$.

MANDAHL-BARTH G (1968). Freshwater molluscs. Explor. Hydrobiol. Bangweulu-Luapala 12 1-68.

MANDAHL-BARTH G, MALAISSE F and RIPERT C (1972) Etudes malacologiques dans la région du lac de Retenue de la Lufira (Katanga), etc. Bull. Soc. Pathol. Exot. 65 146-156.

PITCHFORD RJ (1976) Preliminary observations on the distribution, definitive hosts and possible relation with other schistosomes, of Schistosoma margrebowiei, Le Roux, 1933 and Schistosoma leiperi, Le Roux, 1955. J. Helminthol. 50 111-123.

PITCHFORD RJ and DU TOIT JF (1976) The shedding pattern of three little known African schistosomes under outdoor conditions. Ann. Trop. Med. Parasitol. 70 (2) 181-187.

POTTS WJE (1999) Decision Tree Modeling Course Notes. SAS Institute Inc., Cary, USA.

SCHUTTE CHJ (1966) Observations on two South African bulinid species of the truncatus group (Gastropoda, Planorbidae). Ann. Trop. Med. Parasitol. 60 (1) 106-113.

VAN EEDEN JA, BROWN DS and OBERHOLZER G (1965) The distribution of freshwater molluscs of medical and veterinary importance in south-eastern Africa. Ann. Trop. Med. Parasitol. 59 413-424.

WRIGHT CA (1971) Bulinus on Aldabra and the subfamily Bulininae in the Indian Ocean area. Philosoph. Trans. Roy. Soc. B 260 299-313. 